\section{Science from the top}

Wendy Barnaby reports from Stockholm on the International Foundation for Science's aid programme.

FEw activities can cause such disillusion as the giving of foreign aid. Programmes hailed initially as lifesavers often peter out with the sponsor complaining of lack of cooperation by the receiver, who in turn accuses the sponsor of paternalism or outright exploitation. Often the least satisfactory outcomes seem to bedevil the wealthiest sponsors. Money means organisation and, ipso facto, the diversion of creativity away from aid-giving into the maintenance of the organisation itself.

If wealth tends to bring problems, the International Foundation for Science (IFS) should on the face of it have more success than most aid organisations. Its total revenue for 1976 is expected to be Sk3,560,000 (about $\$ 790,000)$. The organisational side of the IFS looks healthy, too: it was formally established at a meeting in Stockholm last September as an afterthought to the initiation of some 4.5 projects. The only full-time employees are five administrators.

Each project is actually a research grant given to a young scientist from an underdeveloped country on the condition that his or her work is relevant to the needs of the country and carried out in it or some other underdeveloped land. The grants are given annually and are renewable for four years. The original intention behind the scheme was to try to stop the brain-drain of young African, Asian and Latin American scientists to developed countries hecause of the paucity of equipment and contacts at home. The grants-mere are now 100 of themhave all so far been given within the broad field of biology applied to food production.

This encompasses six specific areas. The first is the development of local fish-farming through research on fish, of which an example is a grant of $\$ 13,000$ given to a project in Nigeria's Federal Department of Fisheries to study the distribution of the popular cat-fish in order to collect fingerlings for stocking ponds. The second area is the improvement of small animals (mainly goats and sheep) of domestic and local importance-for example the research being done at the National Agricultural University in Lima to use agricultural waste products as more efficient food for guinea pigs, which are the main source of animal protein for the poor population in the upland region of Peru. The IFS has contributed $\$ 4,600$ to the project. It also supports work on the morphology, physiology and pathology of vegetables, tubers, pulses and forage crops, such as that at the University of Malaya in Kuala Lumpur, to study the protein values of locally grown leaves, stems and tubers from cassava. This studyto which the IFS has given $\$ 2,300$-is aimed at improving cassava for direct human consumption or for the production of leaf protein concentrate.

Studies of mycorrhiza (the symbiotic association of a fungus with the roots of a seed plant) in connection with afforestation form the fourth area of interest. At the Forest Products Research Institute, Kumasi, Ghana, research is being done into the most suitable fungi and the performance of field innoculation of pines with mycorrhizal fungi, the mass production of suitable fungi and the performance of the innoculated pines. The results will, it is hoped, contribute to Ghana's reafforestation programme, and the IFS has supported it with $\$ 13,000$. The fifth area is the improvement of traditional food fermentation processes--for example, a project under way at the University of Ain Shams in Cairo. Egypt, in which the waste materials from industrial food processing are being examined to see if they are suitable for controlled microbial growth which could lead to the economic production of protein. The IFS has given the project $\$ 7,000$. The investigation of organic compounds from natural products traditionally believed to have medicinal applications is the sixth area. Here, the IFS has for example given $\$ 6,300$ to research at the Haile Selassie I University, in Addis Abaha, Ethiopia, into the structure, properties and possible toxicological effects of a local plant used against tape-worm infections.

The fact that the grants are given in so many different places is not the only international aspect of the IFS. The funds are also contributed from many countries, mainly through national academies or other bodies representative of natural or social science or technology. In 1976, Sweden is expected to contribute just over half the total budget, Canada nearly one-fifth, and France, Belgium, the Federal Republic of Germany, the Netherlands and Japan will make up the rest between them. The President of the organisation-and the moving force behind its inception-is Swedish Professor Sven Brohult.

The specific projects mentioned so far illustrate the IFS pattern of a small grant being given to an individual scientist already employed at a research institute in an underdeveloped country. The organisation's involvement does not end there, however. Applications for grants in each of the six areas of interest are perused by scientific advisory groups, who recommend on their adoption to the Grants Committee. The advisers (who work for the IFS voluntarily) are scientists employed on research within the area whose applications they judge, and travelling in the course of their work to the regions in which projects are being carried out. In this fashion, the IFS is building up a network of contacts between researchers working in the same field in neighbouring countries who were not previously aware of each other's existence.

The IFS is so far committed to the potential of developed countries' science for aiding underdeveloped countries, a commitment which grew naturally out of its attempt to stop the brain-drain and one which can be strongly defended given the fact that so many researchers from underdeveloped countries have already been educated abroad. With this commitment goes a "science from the top" approach: support of researchers educated in science working by traditional methods in the hope that their work will ultimately benefit the other sectors of society. This is less fashionable now than the "science from the bottom" approach: educating the masses to contribute to the improvement of their condition through science, as for example Chinese peasants reporting on signs they see in the fields of approaching earthquakes. Ideally, each approach should complement the other. In the meantime, however, the IFS is seen to be doing something worthwhile.

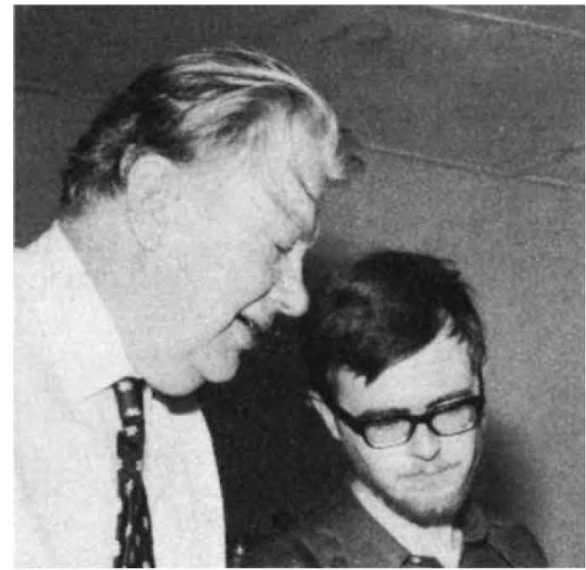

Sven Brohult, IFS President, and Olle Edquist, former Executive Secretary 